DR. FEDERICO FERRETTI - School of Geography, Campus of Belfield, Newman Building, Room H015,+353 1716 8176, federico.ferretti@ucd.ie

\title{
Teaching anarchist geographies: Elisée Reclus in Brussels and "the art of not being governed"
}

\begin{abstract}
This paper addresses the issue of how to teach anarchist geographies, as discussed by the current literature in this field. To this end, I analyse an exceptional archival source, i.e., the notes taken by a student of anarchist geographer Elisée Reclus during the classes that Reclus gave at the New University in Brussels. These notes are the only surviving document able to shed light on the short teaching experience Reclus had at the end of his career (1894-1905). Drawing upon Benedict Anderson's notions of "anti-colonial imagination" and of different "frameworks of comparison", I show how Reclus tried to perform an anarchist geographical teaching by simultaneously embracing empathy toward cultural differences and universal feelings of justice and international solidarity. Therefore, he taught a non-statist geography by showing his students what James Scott calls "the art of not being governed", addressing the examples of the egalitarian traditions of some non-European peoples, together with their anti-authoritarian and anti-colonial struggles. Finally, I explain how this case can help to elucidate the present-day debates on performing radical teaching approaches inside and outside the academy.
\end{abstract}

Keywords: anarchist geographies; geography teaching; empathy; anti-colonialism; Armenian genocide

"Liberty, though primitive, is a higher stage than servile civilisation." E. Reclus, Comparative Geography, Academic Year 1896-97, Lecture 14

This paper addresses the problem of how to teach anarchist geographies, which has been raised by recent works on radical pedagogies (Rouhani 2012; Springer, Lopes de Souza and White 2015) in the context of the international rediscovery of anarchist geographies, their roots and genealogies (Springer 2016, Springer, Ince, Pickerill, Brown and Barker 2012). If anarchist and antiauthoritarian practices are largely discussed in geography, their application to teaching oscillates

"Teaching anarchist geographies: Elisée Reclus in Brussels and 'the art of not being governed", Annals of the American Association of Geographers, 108(1), 2018, p. 162-178 http://www.tandfonline.com/doi/full/10.1080/24694452.2017.1339587 1 
between non-institutional experiences inspired by the concept of de-schooling (Illich 1970) and more pragmatic attempts to work within existing institutions or to practice "unschooling" and home-schooling as concrete options for daily life (Springer 2016b). Recent scholarship on anarchist pedagogies in higher education simultaneously addresses "free schools" and experiments attempted by critical scholars within universities (Noterman and Pusey 2012), and the contradictions implied by academic work for anarchist scholars (Kalterfleiter and Nocella II 2012; Amster 2002). Likewise, critical geographical scholarship committed to "the purpose of a popular geography" (Pulido and Barraclough 2008, 710) is willing to use the possibilities provided by existing institutions without giving up wider relations with grassroots social movements and autonomous spaces (Chatterton 2008).

The famous paper by Pyotr Kropotkin (1842-1921), "What geography ought to be" (1885), is frequently cited as an example of reflection on both what to teach and how to teach in anarchist geographies, though authors like Springer consider that contemporary scholarship should go far beyond in a critique of the very concept of school (Springer 2016b). Yet, few studies have addressed the specific commitment to pedagogy of other early anarchist geographers, especially those from outside the English-speaking world (Ferretti 2016a and b). This paper is an attempt to fill this lacuna. Assuming that "all geographical knowledge is pedagogical and that all pedagogy is political" (Castree et al. 2008, 680) and that "what we teach, and how we teach it are battlegrounds in the struggle for social change" (Chatterton 2008, 419), I contribute to the aforementioned debates by analysing an exceptional source that has never been discussed by scholars: the handwritten notes taken by Camille Platteel (1854-1943), a student at the Brussels Université nouvelle [New University] for the lectures given there by the famous anarchist geographer Elisée Reclus (1830-1905). This is the only document providing details of the teaching activities deployed by Reclus, whose difficult relation to schools and universities is detailed below, while the New University was an original and still understudied experience associated with the international movement of anarchist education at that time (Codello 2005; Avrich 2006; Suissa 2010). A peculiarity of this experience was that it drew not upon primary education but upon higher education, including free auditors and mature students (Dunbar 1978; Despy-Meyer 1984).

"Teaching anarchist geographies: Elisée Reclus in Brussels and 'the art of not being governed", Annals of the American Association of Geographers, 108(1), 2018, p. 162-178 http://www.tandfonline.com/doi/full/10.1080/24694452.2017.1339587 
My main argument is that Reclus's teaching provides insights for today's debates on both the methods and the contents of a possible anarchist or anti-authoritarian geographical pedagogy. First, it shows the importance of education for a project of social transformation and the possibility of carrying it on inside or outside the institutions, maintaining in any case a critical approach to the institutional system of grades and official degrees. Second, teaching anarchist geographies should provide students with the lenses of a radical critique to read the world: the main concept Reclus taught to his students, addressing Asian countries between 1894 and 1897 (the years for which complete notes and syllabi survive), corresponded roughly to what James C. Scott calls today "the art of not being governed" (Scott, 2009). Reclus's teaching presented the societies and communities he analysed as entities traditionally opposed to the political framework of states and boundaries, anticipating contemporary claims for non-statist geographies (Ince and Barrera de la Torre 2016) as well as present-day anti-statist anthropologies (Barclay 1996; Graeber 2004; Morris 2014). Several geographers have highlighted Reclus's anti-colonial, empathic and generous approach to non-European peoples (Clark and Martin 2013; Ferretti 2013a; Mathewson 2016; Pelletier 2013). As Reclus worked during imperial ages, I also argue that his teaching can be considered part of the anarchist anti-colonial imagination as defined by Benedict Anderson (1936-2015) and that Reclus's "comparative geography" can be read through Anderson's transnational "frameworks of comparison". For Anderson, this concept allows us to make sense of early anarchism, informed "by contemporary learning, communications and coordination in connection with ideologies and political activism .... Some Frenchmen were learning from some Americans and Belgians, some Chinese from some Filipinos and Japanese, some Italians from some Spaniards and Russians, some Filipinos from some Germans and Cubans. And so on" (Anderson 2016, 129). Likewise, ideas on how the "West" can learn from other contexts resonate in recent anarchist geographical scholarship on Asian and Latin-American activism (Araujo 2016, Springer 2015).

The main source I address is the 21 notebooks containing Platteel's handwritten notes that survive in the New University Archives in Brussels, now held in the library of the Université Libre (ULB). This document comprises altogether 1,052 pages of notes and drawings (mainly maps) by Platteel and the typed syllabi of the corresponding 60 lectures given by Reclus in the three annual modules that he taught between 1894 and 1897 (1 to 3 pages for each class). Each module was dedicated to

"Teaching anarchist geographies: Elisée Reclus in Brussels and 'the art of not being governed", Annals of the American Association of Geographers, 108(1), 2018, p. 162-178 http://www.tandfonline.com/doi/full/10.1080/24694452.2017.1339587 3 
a monographic argument corresponding to a different area of the globe: in 1894-95, it was Eastern Asia (Tibet, China, Mongolia, Korea and Japan - 21 classes); in 1895-96, the Indian region (19 classes) and in 1896-97, Western and Central Asia (Iran, Mesopotamia, Central Asia and the Caucasus - 20 classes). Analysing this body of sources implies a methodological warning: only the syllabi can properly be considered to be written, or at least supervised, by Reclus, while Platteel's notes and their phrasing do not necessarily reflect the teacher's opinions, as it is impossible to fully establish their degree of "faithfulness" to Reclus's speeches. Thus, I always specify whether I am quoting from the syllabus or the student's notes. The lack of other recordings of Reclus's classes for comparison makes it difficult to assess the "pedagogical relationship" between Reclus and Platteel; thus, I use these notes mainly to reconstruct the modules' contents. Nevertheless, further research might be conducted on the reception of Reclus's teaching among Brussels students.

In the first part of this paper, I discuss the context of the source by addressing the international movement of anarchist pedagogy and Reclus's difficult approach to teaching. In the second part, I address Reclus's teaching on China and India, drawing upon the concept of empathy and the postcolonial imagination. In the third part, I address Reclus's classes on the "Middle East" in the context of a non-statist geography and an early denunciation of genocides.

\section{Anarchist Education in the Age of Empire}

Historians of geography and of scientific movements generally acknowledge the importance of contextual readings and situated approaches to the spaces, localisation and transfers of knowledge in order to overtake the former internalist readings of science (Livingstone 2003; Jöns, Meusburger and Heffernan 2017; Powell 2007). Thus, this section aims to reconstruct the context in which the source I address should be read, especially its main actors (Reclus and Platteel), its places (the New University in Brussels), and its insertion into the international movement of anarchist education.

The movement of anarchist education (or "libertarian pedagogy") opened several experimental and self-managed schools all over the world from the end of the nineteenth century. The most famous examples took place in Spain, Switzerland, France, Great Britain, Italy, United States, Argentina, Uruguay and Brazil (Codello 2005; Avrich 2006). Only recently the contributions early anarchist

"Teaching anarchist geographies: Elisée Reclus in Brussels and 'the art of not being governed", Annals of the American Association of Geographers, 108(1), 2018, p. 162-178 http://www.tandfonline.com/doi/full/10.1080/24694452.2017.1339587 
geographers like Reclus gave to these experiences has become to be considered by geographical scholarship (Ferretti, 2016b). Nevertheless, Reclus was one of the main inspirers of this movement, being the first signatory of the seminal 1898 manifesto for the creation of self-managed anarchist schools, also subscribed by other famous international anarchists such as Louise Michel, Jean Grave, Lev Tolstoy and Kropotkin (Reclus et al., 1898).

The concept of anarchist education owed first to the ideas anarchists such as Paul Robin (18371912) and Charles Perron (1837-1909) advanced within the First International, claiming for considering education not an accessorial activity, but a major issue in the struggle for social emancipation (Perron, 1868). Later, active methods inspired by the Swiss educator Johan-Heinrich Pestalozzi (1746-1827) informed Reclus's and Kropotkin's ideas on education in open air, walks and unhampered physical activities as the first way for teaching geography, in opposition with maps and manuals. Reclus considered that flat maps, carrying with them false and Eurocentric visions of the world, were 'to be entirely forbidden' (Reclus, 1903, 290) in primary education and replaced with globes and with the direct experience of the world. These principles were applied first in France, namely in the Cempuis orphanage, run by Robin and considered as the first experiment in anarchist education (Ferretti, 2016a). Nevertheless, these experiences were not limited to primary school, but informed long-life education because, according to Reclus, "it is not in narrow rooms with grilled windows that brave and honest people can grow" (Reclus 1880, 248).

Exiled during most of his life, Reclus did not have access to university teaching in France, a field monopolised at the time by the fellows of Paul Vidal de La Blache (Robic, Tissier and Pinchemel 2011), despite the interest in teaching he had expressed since the beginning of his activity as a geographer. This interest is shown by Reclus's correspondence, especially a letter he wrote to his mother in 1858: "The idea that I might become a geography teacher is joyful for me" (Reclus 1911, 170-171). Nevertheless, it would be wrong to argue that Reclus was a marginal figure who never managed to establish himself in the academy. In 1890, Reclus refused an appointment he was offered as Chair of Geography at the University of Geneva, arguing that he was too busy completing his New Universal Geography. ${ }^{1}$ This was not an ideological refusal of universities but

\footnotetext{
${ }^{1}$ Bibliothèque de Genève (BGE), Ms. 1739, f 119 E. Reclus to E. Ricard 10 February 1890.

"Teaching anarchist geographies: Elisée Reclus in Brussels and 'the art of not being governed", Annals of the American Association of Geographers, 108(1), 2018, p. 162-178 http://www.tandfonline.com/doi/full/10.1080/24694452.2017.1339587
} 
the mark of a mentality and a historical period when holding a university position was not paramount for a geographer (Ferretti 2014). In 1893, once finished his encyclopaedic work, Reclus accepted a professorship at the Brussels Université libre (Free University).

There, the so-called "Reclus incident" remained forever linked to the story of the New University (Despy-Meyer 1986; Uyttebrouck 1986): in the Free University, two fronts, a conservative and a progressive one, were violently opposed, and the "incident" became the pretext for their definitive rupture (Picard 1894). In December 1893, intimidated by the anti-anarchist climate that followed the attack on the French parliament by the individualist Vaillant, the Academic Council revoked Reclus's nomination, and a group of professors and students resigned to found a new institution, the Université nouvelle, where Reclus and several members of his entourage were invited to teach. Among the others, his brother Elie Reclus (1827-1904) moved to Brussels to teach history of religions, and Elie's son Paul (1858-1941) later joined his elderly relatives. According to Teresa Vicente-Mosquete, Reclus's pedagogical principles "matched perfectly this university which struggled against the reduction of the individual to his mere professional task and fostered a nonvocational and interdisciplinary teaching against excessive specialization" (Vicente 2004, 939). The New University especially welcomed foreign students and teachers and their multilingualism. Nevertheless, this university did not pay its collaborators, and the Belgian government refused to give legal validity to its degrees; once they completed their curricula at the New University, students had to pass a state exam before an external board, where their success was far from guaranteed (Despy-Meyer 1973). Thus, in its 20 years of existence (the New University closed in 1914 with the invasion of Belgium during WWI), the institution was characterised by a strong militant and voluntarist mood, similar to the spirit that animated the experiences of anarchist education in other European countries. The Geographical Institute founded by Reclus at the New University produced globes and didactic materials that were used by some anarchist primary schools, such as the Barcelona Escuela Moderna. ${ }^{2}$ Another characteristic of the New University was that it guaranteed access and "equal rights" (Picard 1894, 641) to women when female access to university was still rare.

\footnotetext{
${ }^{2}$ Bibliothèque Nationale de France, NAF 22914, F. Ferrer y Guardia to E. Reclus, 1 June 1903.

"Teaching anarchist geographies: Elisée Reclus in Brussels and 'the art of not being governed", Annals of the American Association of Geographers, 108(1), 2018, p. 162-178 http://www.tandfonline.com/doi/full/10.1080/24694452.2017.1339587
} 
According to Vicente, more than a thousand people attended the inaugural conference given by Reclus on 2 March 1894 on Comparative Geography in Space and Time in a lecture theatre offered by the local Freemasons. The title explicitly recalled Carl Ritter's classes, which Reclus had attended in Berlin as a student. This was the first of 12 conferences in which Reclus exposed his "conception of geography" (Vicente 2004, 945); it was not documented by Platteel's notes, as the first module she attended started on 27 October $1894,{ }^{3}$ when the New University was formally inaugurated. The experience of teaching was challenging for the elderly Reclus, who was one of the most prolific writers in the history of geography but always considered himself to be a bad speaker. According to an anecdote told with a certain humour by Edmond Picard, Reclus asked permission to read his lectures in class, arguing that "'I am unable to speak'. [Yet, once this permission was obtained,] from the second class onwards Reclus no longer read" (Picard 1897, 558). The text of this first conference was published and shows the importance that Reclus gave to teaching. First, the anarchist geographer highlighted the strategical value of geography for politics and education. "Taken in its narrowest sense, geography ... is one of the most dangerous studies. ... It would be better to avoid learning anything and keep your intelligence free, ready to receive new suggestions, than to fill your brain with infinite notions which do not correspond to any ideal. Why should we care about the names of cities, towns, villages, peoples and tribes? What should we do with the degrees of latitude and longitude, why should we enumerate hundreds and thousands of astronomical coordinates and the infinite inter-crossing of oblique, parallel or perpendicular meridian lines? And with what disdain should we consider this caricature of geography which consists in tracing coloured bars through the continents or even on the moving seas' flow? I invite you to the study of a completely different science" (Reclus 1894a, 4). Amazingly, today the same issues are raised in geographical scholarship, as shown by the recent Springer's claims against gatekeeping for a more encompassing vision of geography beyond the narrowness of data, codification and utilitarian specialities (Springer 2017).

Reclus anticipated present-day cultural geographies, which try to understand the world's representations produced by different cultures beyond positivist assumptions of "accuracy": "In

\footnotetext{
${ }^{3}$ Université Libre de Bruxelles, Archives de l'Université Nouvelle (hereafter ULB), IZ 453, T Dejongh, Les Reclus à l'Université Nouvelle de Bruxelles [typed document], p. 18.

"Teaching anarchist geographies: Elisée Reclus in Brussels and 'the art of not being governed", Annals of the American Association of Geographers, 108(1), 2018, p. 162-178 http://www.tandfonline.com/doi/full/10.1080/24694452.2017.1339587
} 
the Mahābhārata, wise Sanjaya describes his native land as a lotus flower flowing on the water ... and the number of petals varies following ethnic or political divisions, or poets' imagination. In my mind, the great Hindu flower is living, and though it does not correspond to the shape of the Indian region according to modern surveys, it represents India better than the rough blueprint given by Ptolemy within his network of parallels and meridians" (Reclus 1894a, 4). This approach matched Reclus's critiques of flat maps and "cartographic reason" highlighted by recent scholarship (Ferretti 2014b).

In his inaugural conference for the following academic year, Reclus further clarified the tasks of the New University, which challenged schools and universities as places for the "industrial" production of degrees and trampolines for social advancement where, as Kaltefleiter and Nocella argue today, "independent thought is given up in favour of obedience" (Kaltefleiter and Nocella 2012, 203). Blaming utilitarian study and hierarchies, Reclus warned his students: "From the beginning, you must choose between two kinds of intellectual life. [Many] try to simplify their work, learning by heart the formulas of their textbooks, re-masticating sentences pronounced before them by famous professors. ... Against this, we warn you against all formulas and guidebooks which lead to the disgust of books. ... We advise you to mistrust the programs which limit your intelligence, the questionnaires which ankylose it, the summaries which impoverish it, and we advise you to study by yourself with all the enthusiasm of discovery. ... Your goal is not to show that you know, but to know" (Reclus 1895). Reclus's response to the lack of official degrees at the New University was a call to voluntarism and critical, lifelong learning. "The student really in love with knowledge should look with scornful superiority at these end-of-year formalities, these banal exiting exams which will give you an official stamp, symbol of laziness and definitive abandon of studies for the cowards, while for the brave this does not even mean a moment of rest in their endless work. Here you are the price of study's dignity. The choice is up to you" (Reclus 1895). Reclus's claims for active and critical individual work look here like an anticipation of the slogan "do it yourself". Apparently, there was no formal assessment in the modules taught by Reclus.

"Teaching anarchist geographies: Elisée Reclus in Brussels and 'the art of not being governed", Annals of the American Association of Geographers, 108(1), 2018, p. 162-178 http://www.tandfonline.com/doi/full/10.1080/24694452.2017.1339587 8 
Reclus likewise criticised the specialisation and commodification of knowledge by a university "which produces skilled workers to be put in use for the (re)production of capital" (Noterman and Pusey 2012, 175), which characterised classical economics at the time. Reclus blamed people who "recollect lucrative formulas to make gold with them ... Likewise, we should doubt that the usual recommendation repeated to young scholars, to remain narrowly within their speciality ... is really favourable to the individual's intellectual development and to the overall progress of science" (Reclus 1895). The anarchist geographer concluded by responding to a possible objection: "One might ask: but the ideal work you offer to young people is difficult, isn't it almost impossible? For sure, we request a very ambitious work. Did we not adopt the definition of Emerson: 'the savant must be a hero'?" (Reclus 1895). This might sound somehow elitist in today's public universities, but it is worth noting that the "heroes" evoked by Reclus were mostly self-educated proletarians who enrolled themselves in extension programmes and "popular universities" (Ferretti 2016b).

Reclus's lectures for Compared Geography in Space and Time took 1-2 hours per week during the teaching term (Vicente 2004, 942). It is difficult to assess the number of attendees. We know that the number of students who officially registered for the New University was relatively low in the first years: 103 for 1894-95, 115 for 1895-96, and 169 for 1896-97 (Van Rooy 1976, 224). The presence of free auditors was accordingly very important; another student of the 1894-95 year, Thérèse Dejongh, recollected a general "public" 4 attending, and it is said that classes occurred in the evening. Thus, it is possible to tentatively estimate 60-70 people attending these classes and an impact going far beyond if we consider the number of publications produced by the New University and the great international attention that the mainstream press showed it (Van Rooy 1976). It is also possible to infer that Reclus's audience was an international one, because among the "2,623 students" who registered at the New University until 1912, the archives record "522 Bulgarians, 328 Romanians, 424 Russians $^{5}$ and 180 representatives of different nationalities including Cuban and Chinese" (Van Rooy 1976, 225). Concurrently, Reclus was involved in programmes of

\footnotetext{
${ }^{4}$ ULB, IZ 453, T. Dejongh, Les Reclus ..., p. 21.

${ }^{5}$ It is worth noting that the Russian nationality embraced not only Russians but also Poles, Finns, Ukrainians, Armenians and all the other nationalities that were then part of the Russian empire. Most of these migrants were anarchists, socialists, or nationalist political exiles.

"Teaching anarchist geographies: Elisée Reclus in Brussels and 'the art of not being governed", Annals of the American Association of Geographers, 108(1), 2018, p. 162-178 http://www.tandfonline.com/doi/full/10.1080/24694452.2017.1339587
} 
extension for adult proletarians, and his surviving syllabus on South America shows that the format of these classes was not very different from that of the New University classes (Reclus 1894b).

Camille Platteel was a mature student; when she started attending Reclus's classes, she was aged forty and signed her notebooks as "Ms. Camille Platteel, Professor of Geography for the programme of Education B of the City of Brussels". 6 Thus, Platteel was a secondary school teacher, inserted in the general movement of secular and rational education that observed forms of collaboration between anarchists and advanced liberals and affirmation of women in professional teaching (Ferretti 2015 and 2016a). Platteel is mentioned by historians of art as a contact person between anarchists and neo-impressionist painters with an affinity to anarchism, such as Theo Van Rhysselberghe (1862-1926), who was also acquainted with Reclus. According to Joan Halperin, Platteel participated for many years in a ménage à trois with the famous art critic Félix Fénéon (1861-1944) and his official wife; Fénéon was a central figure in the collaboration between anarchists and artists, and Platteel worked with him. She stopped attending Reclus's classes when she moved to Paris to join her lover, and in the following years, she was "in all the avant-garde manifestations, where she knew everyone and everything" (Halperin 1991, 362). This confirms that attending the New University was first a militant act, important for understanding the connection between geographical teaching and activism in the network of early anarchist geographers, who anticipated contemporary critiques of schools' "even-intensifying-alienation" (Springer 2016b, 247), but were also akin to the wider movement for building public and secular popular education (Ferretti, 2016b).

\section{Asia and Anti-Colonial Empathy}

Recent work reconsidering area studies has shown the different political views lying behind the division of the world into different regions (Sidaway et al. 2016), while scholarship on anarchist geographies shows their pioneering efforts towards empathy for different cultures, including reading sources in the original languages (Ferretti 2013a). In the case of "Eastern Asia," Reclus drew on the exceptional multilingual skills of Léon Metchnikoff, who had lived in Japan and

${ }^{6}$ ULB, IZ 456, Cours de Géographie Comparée dans l'Espace et dans le Temps, 1894-95, Carnet 1, lecture 1. All quotations from the original French have been translated by the author.

"Teaching anarchist geographies: Elisée Reclus in Brussels and 'the art of not being governed", Annals of the American Association of Geographers, 108(1), 2018, p. 162-178 http://www.tandfonline.com/doi/full/10.1080/24694452.2017.1339587 10 
understood "Japanese, Chinese, Korean, Mongol, Manchu"7. Anarchist geographers were especially interested in early Chinese socialism, challenging the traditional Euro-centrism of a part of the workers' movements by admitting that Western revolutionaries might learn from other experiences. Arif Dirlik has shown that this exchange operated in two directions, as Chinese militants in touch with the New University and the Reclus family founded an original anarchist movement in China (Dirlik 1991), and Japanese and Korean activists did the same (Pelletier 2013). According to Sho Konishi, exchanges between Russian and Japanese radicals at the time of the Meiji Revolution (1868), inaugurated by Metchnikoff, inspired "a cooperatist anarchist modernity ... beyond western modern constructs" (Konishi 2013, 3-4). In the case of India, Maia Ramnath addresses the history of anarchists' commitment to anti-colonialism as an alternative to decolonisation models drawing upon nationalism and traditionalism (Ramnath 2011). Considering Anderson's aforementioned works, I show below that Reclus's teaching was inserted into the idea of the "anti-colonial imagination".

As a first case for comparison, one can consider Reclus's assessment of Oriental religions such as Buddhism. If the above quotation regarding the Mahābhārata shows Reclus's appreciation for different cultures, his comparative reading of religions in "the West and the Rest" led him to the conclusion that, though with different nuances, religions are instruments of domination everywhere. To understand Reclus's sarcastic comments on religions such as Islam and Buddhism, it is important to consider that this was not the expression of a Euro-centric outlook but a comparative reading in which the criticism of Christian churches was no less harsh. This is also shown by Elie Reclus's lectures on the history of religions; his task was to compare and "deconstruct" the religious myths of different cultures in order to show that religions are human inventions, a task whose relevance for an anarchist political agenda is obvious. ${ }^{8}$ Buddhism, in its Tibetan, Indian and Chinese versions, was analysed both in Elisée Reclus's classes and in his publications, for example, an article he published in 1897 in the Humanité Nouvelle, a journal close to the New University. Reclus had then to address the fashion of mysticism and Oriental religions that was attracting many radical intellectuals and artists, including some of Reclus's friends, such

\footnotetext{
${ }^{7}$ Bibliothèque Nationale de France, NAF, 16798, f 3, É. Reclus to P. Pelet, 11 January 1881.

${ }^{8}$ ULB, IZ 455, Cours de M. Elie Reclus, Evolution des Réligions, 1898-1903.

"Teaching anarchist geographies: Elisée Reclus in Brussels and 'the art of not being governed", Annals of the American Association of Geographers, 108(1), 2018, p. 162-178 http://www.tandfonline.com/doi/full/10.1080/24694452.2017.1339587 11
} 
as Alexandra David-Neel (Brun 2015). Thus, he compared early Buddhism to early Christianity, arguing that the "superficial views of some historians of Buddhism" (Reclus 1897, 140) failed to explain this movement, which he considered a revolutionary "attempt towards equality, a shock against the detestable institution of castes" (Reclus 1897, 141). Nevertheless, according to Reclus, as Christian egalitarianism ended when Constantin rendered it the state religion, so "Buddhism left definitively its true social character when King Asoka proclaimed the cult of çakya Mouni as the state religion, appointing 64,000 priests-functionaries" (Reclus 1897, 143).

In Reclus's lectures on Tibet, this comparative anti-clericalism shows clearly in the geographer's remarks on the absolute theocratic power of the Dalai Lama and in his blame for the "social and political consequences of religious servitude" 9 and for the repressive practices of the theocratic regime against dissidents, who suffered the "worst tortures"10. According to Reclus, political centralisation was a cause of social degradation; thus, he considered the Lama's despotism to be one of the aspects that favoured the Chinese colonial conquest of Tibet: "In a country completely subjugated to the authority of just one man, it was enough to hit the head for submitting the entire social body". ${ }^{11}$ Likewise, Reclus's irony was sharp towards Catholic missionaries in the region, whom he accused of "work for taking the Dalai-Lama's place". ${ }^{12}$

In the lectures addressing the history of Mongolian invasions, Reclus laughed at the Euro-centric invention of "Prester John", which he deemed a "religious hallucination", by European travellers in the Middle Ages. ${ }^{13}$ This European projection was created to hide the religious tolerance of the Mongols, which was intolerable to members of the Christian church, according to Reclus: "Mongols were mentors of fraternity and tolerance, which were an outcome of the freedom of thinking". ${ }^{14}$ Against European stereotypes of the barbarity of the inhabitants of the Asian Steppe, Reclus expressed his sympathy for the nomadic Mongol tribes, which allowed Genghis Kahn and their other leaders to gain numerous military successes thanks to the "Mongols' moral superiority

\footnotetext{
${ }^{9}$ ULB, IZ 456, 1894-95, Carnet 2, Lecture 1, Syllabus.

${ }^{10}$ ULB, IZ 456, 1894-95, Carnet 2, Lecture 1, Platteel's notes.

${ }^{11}$ ULB, IZ 456, 1894-95, Carnet 2, Lecture 1, Platteel's notes.

${ }^{12}$ ULB, IZ 456, 1894-95, Carnet 2, Lecture 1, Platteel's notes.

${ }^{13}$ ULB, IZ 456, 1894-95, Carnet 3, Lecture 6, Syllabus.

${ }^{14}$ ULB, IZ 456, 1894-95, Carnet 3, Lecture 6, Platteel's notes.

"Teaching anarchist geographies: Elisée Reclus in Brussels and 'the art of not being governed", Annals of the American Association of Geographers, 108(1), 2018, p. 162-178 http://www.tandfonline.com/doi/full/10.1080/24694452.2017.1339587 12
} 
resulting from their voluntary assembly under the authority of freely elected chiefs". ${ }^{15}$ Thus, the end of the Mongol empire and the raising of the Manchu dynasty are seen by Reclus as corresponding to the introduction of rigid social hierarchies, the "suppression of popular assemblies" and the advent of "courtesanerie."16 This perspective upsets traditional European views on progress from the "barbarian" to the "civilised" stages. As recent scholarship has shown, Reclus and other anarchist geographers used definitions such as "barbarians" and "primitive" without any assumption of ethnic superiority, having a relative view of progress and a special appreciation for primitive forms of communism and radical democracy (Ferretti 2016b and 2017).

Among the other Asian regions addressed by Reclus, Manchuria and Korea were examples of a geopolitical analysis of empires because they were the objects of imperial rivalries between Russia, China and Japan. The Korean peninsula was presented as a territory historically disputed by Japan and China, resulting in the "Koreans' subjugation," which implied Korea's "subalternity as a centre of political power". ${ }^{17}$ This proves Reclus's attention to colonial relations of power in different regions and on different scales. Reclus also drew on Metchnikoff's ideas on raising Japan's imperial potential as a new global maritime empire, considered to be a contribution to the progressive conceptual reshaping and provincialising of European hegemony undertaken by early anarchist geographers (Ferretti 2011). Anticipating Konishi's argument on multiple, and not necessarily European, possible modernities, Reclus defined the Meiji period as a "scientific, social and political revolution", ${ }^{18}$ addressing globalisation as a potentially egalitarian process in which the geographical principle of world unity should favour international brotherhood. The importance of non-European actors in this process was deemed decisive: if one had to assess Reclus's mistake today, it would clearly be optimism more than ethnocentrism. The geographer argued that Japan's entrance into globalisation "strengthens humankind's unity in the most heroic way, putting the extreme Orient close to the extreme Occident. The natural planet's unity ... is today completed by the unity of humankind". 19

${ }^{15}$ ULB, IZ 456, 1894-95, Carnet 3, Lecture 6, Platteel's notes.
${ }^{16}$ ULB, IZ 456, 1894-95, Carnet 3, Lecture 7, Syllabus
${ }^{17}$ ULB, IZ 456, 1894-95, Carnet 3, Lecture 7, Syllabus
${ }^{18}$ ULB, IZ 456, 1894-95, Carnet 4, Lecture 9, Syllabus
${ }^{19}$ ULB, IZ 456, 1894-95, Carnet 4, Lecture 9, Platteel's notes
"Teaching anarchist geographies: Elisée Reclus in Brussels and 'the art of not being governed"”, Annals of the American Association of Geographers, 108(1), 2018, p. 162-178 http://www.tandfonline.com/doi/full/10.1080/24694452.2017.1339587 13 
However, the anarchist geographers' appreciation for "modernity" was always balanced by their interest in the so-called "primitives", meaning not only the denunciation of colonial massacres but also appreciation for first peoples' social institutions, which in most cases were considered egalitarian and capable of inspiring Western socialism rather than simply being overtaken by the diffusion of European ideas (Ferretti 2017). In Japan, Reclus showed a great interest in the aboriginal population of the Ainos (Pelletier 2013), and their "egalitarian customs ... [and] feeble authority of chiefs", including "women's equality"20. According to the early anarchist geographers, it was abusive to give moral assessments of the intelligence of other peoples because their strategies were adapted to different environmental circumstances. In the case of the Ainos, mutual aid was "necessary to live in so unfavourable a country". ${ }^{21}$ Reclus's description of these egalitarian customs was very appreciative: "A chief conserved his authority as far as everybody agreed with his behaviour. ... There is no caste, not even the sacerdotal one. Every Aino celebrated his cult and there was no intermediary between him and the divinity". ${ }^{22}$ The geographer lamented the arrival of “civilisation", represented by the Japanese "merchants' caste which dominates today and [their] authority. ... Today, the Ainos' land has been taken by the Japanese who rule them while formerly their country was remarkable for its quasi absence of government". The "murderous civilisation" produced depopulation and demoralisation; at that time, according to Reclus, "Ainos don't care for life and suicides are frequent among them". ${ }^{23}$

Regarding Meiji modernisation, Reclus did not fail to insert it into the context of global colonial relations, considering it first as a reaction to European imperialism by the Japanese in order "to avoid collapsing under the strangers' pressure. Europeans would have inevitably tried to impose their rule to Japan under the pretext of bringing 'civilisation", ${ }^{24}$ The rising geopolitical power of Japan was also seen as a result of this "revolution", and the 1894-95 war with China, which Japan was winning, as a suggestion for Western powers to direct their interests towards the weaker of the two nations. "Europeans arrange for picking up the pieces of defeated China, under the pretext of defending their present possessions in Tonkin for the French, and to keep Hong-Kong for the

${ }^{20}$ ULB, IZ 456, 1894-95, Carnet 4, Lecture 11, Syllabus

${ }^{21}$ ULB, IZ 456, 1894-95, Carnet 4, Lecture 11, Platteel's notes

${ }^{22}$ ULB, IZ 456, 1894-95, Carnet 4, Lecture 11, Platteel's notes

${ }^{23}$ ULB, IZ 456, 1894-95, Carnet 4, Lecture 11, Platteel's notes

${ }^{24}$ ULB, IZ 456, 1894-95, Carnet 5, Lecture 13, Platteel's notes

"Teaching anarchist geographies: Elisée Reclus in Brussels and 'the art of not being governed", Annals of the American Association of Geographers, 108(1), 2018, p. 162-178 http://www.tandfonline.com/doi/full/10.1080/24694452.2017.1339587 14 
British". ${ }^{25}$ Though Reclus often repeated that the importance of East Asia's rising could hardly be exaggerated, this entailed the necessity of stressing solidarity links between activists to face the globalisation of imperialist capitalism. "The war between Orient and Occident is also an industrial one. ... Thus, the social war is even more urgent". ${ }^{26}$

In addressing China, Reclus's ideas were a far cry from the current commonplaces about its "decadence" and from Euro-centric ideas of civilisation. He argued that China contained "more than one-fourth of the world population and accordingly more than half of civilized people." 27 Likewise, Reclus challenged European views "related to an alleged immutability of China and its institutions". ${ }^{28}$ Among the main interesting points for Reclus were the traditions of collective work. According to Metchnikoff, the ancient fluvial civilisations of Egypt, Mesopotamia, India and China had to choose between two alternatives in order to cope with their environment: "Either being all freely associated, with equal right, or being all the slaves of a master, indigenous or stranger" (Metchnikoff 1889, 227). This argument was used to provide an historical ground for the concept of mutual aid (Metchnikoff 1886), and Reclus applied the same conceptual framework to explain the introduction of private property in Chinese history, which led to the loss of "the solidarity feelings which united the people: collective property disappeared with them". ${ }^{29}$ Drawing upon Metchnikoff's works, Reclus argued that there was "absolute community of land in the first tomes of the Huang-He colonisation," followed by a "ceaseless struggle between warrior feudality and rural democracy", 30

Chinese history showed that socialism was not a European monopoly. In Reclus's syllabus, we find the following title: "Triumph of Chinese revolutionary socialists, nine hundred years before us." 31 In the New Universal Geography, Reclus had argued that the experience of the Chinese socialist leader Wagantche, who set a regime of state communism (under royal supervision) in the eleventh

${ }^{25}$ ULB, IZ 456, 1894-95, Carnet 5, Lecture 13, Platteel's notes

${ }^{26}$ ULB, IZ 456, 1894-95, Carnet 5, Lecture 13, Platteel's notes

${ }^{27}$ ULB, IZ 456, 1894-95, Carnet 5, Lecture 14, Syllabus

${ }^{28}$ ULB, IZ 456, 1894-95, Carnet 5, Lecture 14, Syllabus

${ }^{29}$ ULB, IZ 456, 1894-95, Carnet 5, Lecture 15, Platteel's notes

${ }^{30}$ ULB, IZ 456, 1894-95, Carnet 6, Lecture 19, Syllabus

${ }^{31}$ ULB, IZ 456, 1894-95, Carnet 6, Lecture 19, Syllabus

"Teaching anarchist geographies: Elisée Reclus in Brussels and 'the art of not being governed", Annals of the American Association of Geographers, 108(1), 2018, p. 162-178 http://www.tandfonline.com/doi/full/10.1080/24694452.2017.1339587 15 
century, provided insights into the ongoing debates between anarchism and Marxism. "A change of King was enough to overthrow the new regime, which did no longer correspond to the people's desires ... and which also created a new class of functionaries who had become the true landlords" (Reclus 1882, 577-78). The first lesson for European socialists was that state communism would have led to the rise of a new privileged class, the second that class struggle should become globalised to undertake the challenge of globalised capital. "Class struggle exists in Orient and in Occident, because inequalities are increasing. Thus, popular revolts are numerous ... a universal movement prepares a universal transformation. ... Already at the time of Confucius, philosopher Mengzi wrote that 'men are equal'.... The true rebel is the one who embraces all humankind." 32 Dirlik defined the work of the twentieth-century Chinese anarchist Li Shizeng, who was in touch with the Reclus family, as "a genuinely cosmopolitan world outlook by bringing a Chinese voice into a sociology of human development that had hitherto been dominated by European conceptions" (Dirlik 1991, 289-90). This rooted cosmopolitanism, ceaselessly seeking a balance between local diversities and universal, characterised the anarchist geographical tradition and its pedagogies.

On the plan of colonial relations, Reclus observed that despite all European proclamations, the Chinese were resisting both the Russian expansion and the Anglo-French penetration, which "progresses slowly". ${ }^{3}$ In L'Homme et la Terre, the anarchist geographer also sarcastically condemned the Europeans' attitude during the nineteenth century's "opium wars". "Great Britain could hardly state its 'superior civilisation' when imposing the use of this poison to its customers under thread of bombardment and attack. But this political crime was nothing new. ... Which European trading nation might avoid the blame of having sold ... adulterated liquors and other murderous products?" (Reclus 1905, 166). Regarding Chinese internal colonialism, Reclus observed the "pushing back of aboriginal nations outside the historic routes, in the mountain regions", 34 mentioning some of the ethnic groups that were then the object of James Scott's studies on Zomia. Though Reclus did not have much information about this region and addressed mainly the "art of not being governed" in other areas, as I explain below, his remarks on the Miao's

${ }^{32}$ ULB, IZ 456, 1894-95, Carnet 6, Lecture 20, Platteel's notes

${ }^{33}$ ULB, IZ 456, 1894-95, Carnet 6, Lecture 17, Syllabus.

${ }^{34}$ ULB, IZ 456, 1894-95, Carnet 6, Lecture 18, Syllabus.

"Teaching anarchist geographies: Elisée Reclus in Brussels and 'the art of not being governed", Annals of the American Association of Geographers, 108(1), 2018, p. 162-178 http://www.tandfonline.com/doi/full/10.1080/24694452.2017.1339587 16 
diaspora anticipate Scott's statement that "civilization can't climb hills" (Scott 2009, 20). Scott argues that the people who were pushed back were not necessarily "aboriginals"; likewise, Reclus supposed that new circumstances could lead to the giving up of certain levels of material civilisation. "Some aboriginal populations like the Miao .... constituted republics and still live separated by the Chinese. ... Many of the aboriginal populations which had a higher civilization than their conquerors, came back ... to the Iron Age." 35 In the New Universal Geography, Reclus had stated that “the Miao can't afford the Mandarins' oppression and remain in a state of permanent revolt", blaming the Chinese repression, which included "villages destruction and ... dreadful tortures" (Reclus 1882, 422).

The 1895-96 module was dedicated entirely to India, considered by Reclus as one of the examples of a country in which "there are still a lot of problems to resolve without using ... methods of oppression and enslavement too often used by colonizing countries". ${ }^{36}$ The first colonial issue that Reclus analysed in his classes was the rivalry between the Russian Empire and the British one, which were then coming into contact in Afghanistan, in spite of Lord Salisbury's statements that there was no risk of war because these empires were separated by "inhabited and unreachable extensions. [Yet,] the Russian and British Empire touch each other on a length of approximately 500 kilometres." 37 This led Reclus to contrasting statements: on the one hand, a global war "never was more imminent than now"; on the other, globalisation favoured the development of feelings of solidarity and justice, "which are growing despite frontiers and will englobe all the people, regardless their nation, in the same feeling of brotherhood". ${ }^{38}$ As witnessed by Platteel's notes, these calls for brotherhood often concluded Reclus's lectures, confirming the militant nature of this teaching experience.

India was also a key example for Reclus's distinction between invaded colonies and settler colonies. For Reclus, the weakness of British rule in India was due to the nature of its military and administrative occupation without any appreciable settlement. "The English are few in comparison

\footnotetext{
${ }^{35}$ ULB, IZ 456, 1894-95, Carnet 6, Lecture 18, Platteel's notes.

${ }^{36}$ ULB, IZ 456, 1895-96, Carnet 7, Lecture 1, Platteel's notes.

${ }^{37}$ ULB, IZ 456, 1895-96, Carnet 7, Lecture 2, Platteel's notes.

${ }^{38}$ ULB, IZ 456, 1895-96, Carnet 11, Lecture 10, Platteel's notes.

"Teaching anarchist geographies: Elisée Reclus in Brussels and 'the art of not being governed", Annals of the American Association of Geographers, 108(1), 2018, p. 162-178 http://www.tandfonline.com/doi/full/10.1080/24694452.2017.1339587 17
} 
to Hindus ... almost all the residents are functionaries or soldiers. There are also some landlords and travellers, but the English nation is not really represented." ${ }^{\prime 9}$ The British tactic was then to divide and rule, drawing first on ethnic differences. "The English recruit their best soldiers in Nepal, the Khas or Gurkhas. ... They consider themselves superior to civilians, whom they despise and hate; the English consider them as reliable soldiers and employ them in Asia and South Africa (and now in Rhodesia). ... Thus, every conquering nation must put peoples the one against the other." 40 However, Reclus's reading was not a Manichean division between oppressors and oppressed, because he realised the contradictions inherent in colonisation later discussed by postcolonial literature (Chakrabarty 2000), for instance, the fact that European oppression also exposed the colonised countries to new ideas and technologies that could allow them to rise up and rid themselves of their masters. "The English brought them their industry, their science ... but not freedom. If one day we can bring happiness to the Hindu, it will be only when ... there will be no longer hungry people and we will be free as well."41 Again, the colonial question was seen as strictly linked to the social one and needing reciprocity: Reclus quoted in comparison the bestknown example of a colonised nation in Europe: "So the Polish said to the Russians: we fight for our freedom and for yours." 42

Regarding aboriginal and "fugitive" people, Reclus addressed their history in the context of colonial relations. On the one hand, he relied on the historical hypothesis of the "Aryan invasions", though taking critically the racial categories then viewed as hegemonic and criticizing ideas on the "alleged Aryan race" (Reclus 1905, 505) in L'Homme et la Terre. On the other, he applied again the model that considered inhospitable environments as refuges for unruly communities. "Where to seek the Indian autochthon populations? ... On the Himalaya versants or in the regions of the fevers". The repression of losers is likewise highlighted: "The winners considered them as rebels deserving extermination. Invaders always consider the people who try to reject them as rebels." 43 According to Reclus, British rulers supported Indianisation of aboriginal groups in order to

${ }^{39}$ ULB, IZ 456, 1895-96, Carnet 8, Lecture 3, Platteel's notes.

${ }^{40}$ ULB, IZ 456, 1895-96, Carnet 1 Lecture 9, Platteel's notes.

${ }^{41}$ ULB, IZ 456, 1895-96, Carnet 10 Lecture 7, Platteel's notes.

${ }^{42}$ ULB, IZ 456, 1895-96, Carnet 7 Lecture 2, Platteel's notes.

${ }^{43}$ ULB, IZ 456, 1895-96, Carnet 11 Lecture 9, Platteel's notes

"Teaching anarchist geographies: Elisée Reclus in Brussels and 'the art of not being governed", Annals of the American Association of Geographers, 108(1), 2018, p. 162-178 http://www.tandfonline.com/doi/full/10.1080/24694452.2017.1339587 18 
establish social hierarchies and complete the "abolition of communitarian land property." 44 The best example of this colonial transformation was the massacre of the Santal, a people whose egalitarian traditions have been addressed by Harold Barclay (1996). "Before the arrival of Mongol conquerors and the English, the Santal lived under a regime of communitarian property. Overwhelmed by taxes ... they resorted to usurers who became the masters of the land. The Santal ... appealed desperately to the English government to recover their land and freedom. They were not listened to; thus, they decided to go see the viceroy in Calcutta. ... When this army of miserable went to the plain ... the government believed it was an insurrection and sent against them battalions which massacred twenty thousand peoples and dispersed the others, raging on their villages. ... Shameful collective crime." ${ }^{45}$

In Reclus's narrative, another issue was the regime of the castes. Sensitive to local cultures but not available to give up universal values such as the principle of equality, Reclus explicitly raged against the castes regime, considering that, throughout human history, they were constituted "in all countries in proportion of the monarchist or theocratic power's force" 46 and defining them as "abominable". ${ }^{47}$ Nevertheless, the Europeans were not liberators, as stated in sarcastic notes as a line of Reclus's syllabus: "Caste of thieves, among whom the English chose their police agents". ${ }^{8}$ According to Reclus, the caste system was fated to disappear, but this would be a complex process that would owe nothing to the merit of the colonisers. Reclus considered that the British played a "positive" role in combating oppressive traditions such as the sacrifice of widows but that they also fostered social inequalities to secure their control. However, "in certain places, castes were abolished by will of their former components." 49 If a first attempt to overthrow the caste regime was the "social revolution" 50 attempted by early Buddhism, the other local force that challenged this system, according to Reclus, was the Muslims. Reclus explains the success of Islam in the Indian region by its proselytism in the lower classes and marginalised ethnic groups. "To escape

${ }^{44}$ ULB, IZ 456, 1895-96, Carnet 12 Lecture 11, Syllabus

${ }^{45}$ ULB, IZ 456, 1895-96, Carnet 12 Lecture 11, Platteel's notes

${ }^{46}$ ULB, IZ 456, 1895-96, Carnet 13 Lecture 13, Syllabus

${ }^{47}$ ULB, IZ 456, 1895-96, Carnet 13 Lecture 13, Platteel's notes

${ }^{48}$ ULB, IZ 456, 1895-96, Carnet 13 Lecture 13, Syllabus

${ }^{49}$ ULB, IZ 456, 1895-96, Carnet 13 Lecture 13, Platteel's notes

${ }^{50}$ ULB, IZ 456, 1895-96, Carnet 13 Lecture 14, Syllabus

"Teaching anarchist geographies: Elisée Reclus in Brussels and 'the art of not being governed", Annals of the American Association of Geographers, 108(1), 2018, p. 162-178 http://www.tandfonline.com/doi/full/10.1080/24694452.2017.1339587 19 
the narrow frame of castes, many Hindu were converted and enjoyed more equality and freedom. [Still today] the desire of equality pushes several Hindus to become Muslims. ... In Southern India some Nahir became Muslims and were then respected". ${ }^{11}$ Again, Asian societies were not represented as immobile but as the result of a complex history and of multiple agencies producing subaltern spaces whose study is characterised today, according to Tariq Jazeel, by "uncertainty and translation" (Jazeel 2014, 99). For Reclus, the common goal of Eastern and Western subalterns was social liberation; the lecture on castes concluded quoting a sentence traditionally attributed to Etienne de la Boétie: "The great are only great because we are on our knees: Hindu people started becoming aware of this and thus they begin to rise up". 52

Another issue that Reclus addressed was women's liberation. The anarchist geographer collaborated with the first feminist associations and studied anthropological literature in order to find historical examples of matrilineal descent to show that patriarchy was not ineluctable (Ferretti 2016a). According to him, the rise of patriarchy paralleled the introduction of war and property: "War allowed men to rise in society. Warrior chiefs, usurping privileges, became masters of great properties while becoming family chiefs. In this way, patriarchy appeared." ${ }^{\circ 3}$ In India, Reclus argued that "there are also castes in the family, because a great part of population is oppressed, but the woman is the most oppressed of all". ${ }^{54}$ The liberation of Indian women, according to Reclus, would come about by "gradual abolition of ancient family institutions [and] by education". 55 However, this would not be a Europeans' gift, as a certain equality was embedded in the egalitarian institutions of "aboriginal" people. Moreover, in the "ancient Indian literary works ... women seem to be represented as equal as man. ... When this equality existed, human nature seems perfect to me". ${ }^{56}$ If this narration looks idealised, it is worth noting that recent scholarship addressing subaltern spaces in India has stated the importance of forms of resistance and women's agency on the micro-scale within local societies (Legg 2016)

${ }^{51}$ ULB, IZ 456, 1895-96, Carnet 13 Lecture 14, Platteel's notes

${ }^{52}$ ULB, IZ 456, 1895-96, Carnet 13 Lecture 14, Platteel's notes

${ }^{53}$ ULB, IZ 456, 1895-96, Carnet 12 Lecture 11, Platteel's notes

${ }^{54}$ ULB, IZ 456, 1895-96, Carnet 14 Lecture 15, Platteel's notes

${ }^{55}$ ULB, IZ 456, 1895-96, Carnet 14 Lecture 15, Syllabus.

${ }^{56}$ ULB, IZ 456, 1895-96, Carnet 14 Lecture 15, Platteel's notes

"Teaching anarchist geographies: Elisée Reclus in Brussels and 'the art of not being governed", Annals of the American Association of Geographers, 108(1), 2018, p. 162-178 http://www.tandfonline.com/doi/full/10.1080/24694452.2017.1339587 20 
Finally, revolutionary perspectives are analysed by Reclus with a certain optimism as he argues that the common struggle against the colonisers would overcome the ethnic divisions accentuated by the Western press. "The Muslims did the 1857 mutiny not because they believed that their cartridges were lubricated with lard but for hostility towards the English. ... If the English could defeat this tremendous uprising, it is because they sent against the Muslims their historical enemies, the Gurkha and the Sikh." ${ }^{57}$ According to Reclus, "future revolution will be done in India from

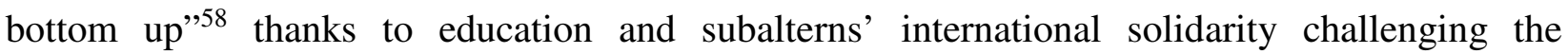
international colonialism exemplified by the comparison between famines in India and Ireland, where liberal capitalists "extract from peasants the most possible profit and only leave them what is strictly necessary to survive. India suffers today from the same regime which ruined Ireland." ${ }^{, 59}$ While this section has shown the central place that disseminating international solidarity and the anti-colonial imagination had in Reclus's teaching in the cases of Eastern Asia and India, I explain below how a critical geohistory of Central and Western Asia contributed to Reclus's critique of state geographies.

\section{A Stateless Geopolitics of the "Middle East"}

In his third academic year, 1896-97, Reclus addressed the wide area including Iran, Touran, Caucasie et Mésopotamie, spanning roughly from the internal areas of the "Middle East" and the Caucasus towards Iran and Uzbekistan. If this regional framing was influenced by scientific theories such as the "Aryan" migrations from Bactrian and Central Asia, which after Edward Said (1978) are considered a scientific invention (and Reclus could rely only on the sources available at his time), I address his third module in order to highlight some of Reclus's original points in constructing what might be called a "stateless geopolitics" that studied local communities beyond the institutional frameworks of the modern invention of territory (Elden 2013).

The first geopolitical issue under Reclus's analysis was again the colonial rivalry between Russia and Britain. In L'Homme et la Terre, Reclus argued that the king of Persia "rules only formally" (Reclus 1905, 493), and his country was "a corpse disputed by two carnivore[es]" (1905, 494),

${ }^{57}$ ULB, IZ 456, 1895-96, Carnet 14 Lecture 17, Platteel's notes

${ }^{58}$ ULB, IZ 456, 1895-96, Carnet 14 Lecture 17, Platteel's notes

${ }^{59}$ ULB, IZ 456, 1895-96, Carnet 14 Lecture 18, Platteel's notes

"Teaching anarchist geographies: Elisée Reclus in Brussels and 'the art of not being governed", Annals of the American Association of Geographers, 108(1), 2018, p. 162-178 http://www.tandfonline.com/doi/full/10.1080/24694452.2017.1339587 21 
British and Russian. From the standpoint of geopolitical power, Russia was considered to be more favoured than Britain in the region, having a continental foothold and a demographic strength in Asia. Gerry Kearns has shown the connections between anarchist geographies' geopolitics and conservative views of the Heartland by Halford Mackinder (Kearns 2009); here, I analyse the complex discourse performed by Reclus on the "annexation of Asia by Europe". On the one hand, Reclus was confident in the dissemination of "progressive" ideas and communitarian institutions such as the Russian mir; on the other, he fumed at imperialism and its effects, which he defined: "Inoculation of Asian customs and spirit, russification of European powers. Fatal regressions coming from Asian annexations and colonial conquests."60

This "russification" was a sarcastic and provocative statement against the alleged "barbarianism" of Russian conquerors that the Western press opposed to the alleged "civilisation" of the French and British ones. Reclus laughed at this contradiction, arguing that as a Frenchman, he felt "humiliated by the [1893] Franco-Russian agreement. Human rights have been proclaimed more than one century ago [the 1789 Declaration], and today there is nobody to cry 'Free Poland!'"61 The contradictions between the universalist idea of human rights and Europeans' behaviour overseas was highlighted by Reclus in stating the oppressive nature of all imperial powers. If France allied opportunistically with Russia, on the other side, "England and Germany now fear an Asian emperor, a descendant of Genghis Khan, who disposes of Asian genius and European civilization. Then, we pounced on Africa not for fraternity, but because there is money to gain." Reclus laughed at current commonplaces on the "barbarians": "For sure, Mongols and Tartars are our brothers, but this is not a reason to assume their vices and their slavery." 62

Addressing the wide area around the Caucasus and Northern Mesopotamia, Reclus mentioned a number of ethnic particularities to which he applied a concept then commonplace in European Romanticism, the so-called "Swiss liberty." ${ }^{3}$ In Reclus's thought, this idea anticipated some features of the "geographies of non-state" by James Scott, such as the mountains' freedom, which

${ }^{60}$ ULB, IZ 457, 1896-97, Carnet 1 Lecture 2, Syllabus.

${ }^{61}$ ULB, IZ 457, 1896-97, Carnet 1 Lecture 2, Platteel's notes.

${ }^{62}$ ULB, IZ 457, 1896-97, Carnet 1 Lecture 2, Platteel's notes.

${ }^{63}$ ULB, IZ 457, 1896-97, Carnet 1 Lecture 3, Syllabus.

"Teaching anarchist geographies: Elisée Reclus in Brussels and 'the art of not being governed", Annals of the American Association of Geographers, 108(1), 2018, p. 162-178 http://www.tandfonline.com/doi/full/10.1080/24694452.2017.1339587 22 
cannot be accounted for by "standard modern maps" (Scott 2009, 47). Reclus tried to make sense of this concept, first by extending it to regions outside Europe. Second, he stated the limitations of the freedom enjoyed by isolated communities: "Can a people consider itself free when there are slaves nearby? We will only be free when the last unfortunate will emancipate". ${ }^{64}$ In any case, the freedom of minorities was not idealised by Reclus, who highlighted the repeated persecutions they suffered. For example, the Zoroastrian peoples, such as the Ezidi, were accused of being “Devil's worshippers" by their neighbours: "Muslims and Christians despise them because they are 'Bookless' people”. Drawing again upon comparison, Reclus stated ironically that "not only Persia, but every society has evil's worshippers. They are ... those who take advantage of their power for acting evilly without being punished". Consistent with his anti-clericalism, Reclus concludes that "persecutors' religions are also dying". 65

In the case of the Caucasian massif, Russian imperialism was equally the central topic, accompanied by its "exterminations and mass deportations". 66 According to Reclus, these mountains had always sheltered a myriad of independent peoples, thus favouring the complexity of the ethnic mosaic. Modernity arrived by way of the invaders, and the geographer observed that "today, all this region is subjugated and many people exterminated, some valleys are deserted." ${ }^{\prime \prime}$ According to Reclus, local divisions were again the explanation for the conqueror's victory, leading to the ethnic cleansing of peoples such as the Circassians and the Chechens. Thus, the Chechens were defeated by the Russians because they failed to establish alliances with neighbouring peoples as these groups were attacked one by one by the czar's armies. Privilege and religion were indicated by Reclus as the reasons for their defeat: in 1829, different tribes willing to resist Russia stipulated an alliance under the direction of Muslim priests. "But these new leaders became an aristocracy whose interests diverged from the original ones. The interests of their tribes were sacrificed to their personal ones. Many joined Russian ranks, and the alliance was broken. ... [Independentist leader] Chamil had to surrender with the last 400 men which remained true to the independence's cause. The Russians wanted to impede a rebellion for ever. Most of the population had perished during

${ }^{64}$ ULB, IZ 457, 1896-97, Carnet 1 Lecture 3, Platteel's notes

${ }^{65}$ ULB, IZ 457, 1896-97, Carnet 3 Lecture7, Platteel's notes

${ }^{66}$ ULB, IZ 457, 1896-97, Carnet 4 Lecture 11, Syllabus

${ }^{67}$ ULB, IZ 457, 1896-97, Carnet 4 Lecture 11, Platteel's notes

"Teaching anarchist geographies: Elisée Reclus in Brussels and 'the art of not being governed", Annals of the American Association of Geographers, 108(1), 2018, p. 162-178 http://www.tandfonline.com/doi/full/10.1080/24694452.2017.1339587 23 
the war. Villages were destroyed and remaining people deported." ${ }^{\prime 68}$ However, Chechenia was not the only case of Reclus's denunciation of what we call today a genocide, as I explain below.

Other mountain communities interested Reclus among the "small republics of equals" in the Caucasus region, such as the "mountains' Jews", 69 whom he praised as important intermediaries between different warrior tribes because they were allowed to travel freely for trade. Again, Reclus challenged commonplaces about the Jews as a people of traders and bankers, providing a contradictory example: "In Dagestan, Jews are not merchants, they consider that doing commerce would dishonour them. If they lend money, it is without any interest, and there is no poor in their communities. Personal property exists, but nobody has the right to become rich beyond a certain level. ... It is tacitly agreed that the community [helps] disabled people who cannot earn their life". ${ }^{70}$ These forms of communitarian mutual aid were paramount for the anarchist geographers' idea of mountain freedom and for their study of human adaptation to the environment. Another example praised by Reclus was that of some Lezgin villages that sheltered the survivors of other communities destroyed by wars, arguing that, in such places, "people are the freest. These communities are similar to those of the Kabyles. Equality of rights is established among their members, and everybody is involved in the commune: men, women, children. Doubtless, these communitarian assemblies are today replaced by the Russian Zarost, ruling on behalf of the Czar."71 It is not coincidence that for this comparison, Reclus mentioned another extra-European colonised people, the Kabyles, whose egalitarian traditions he had used as an argument against French colonialism in Algeria (Ferretti 2013).

A people that intrigued Reclus was the Armenians, whom he compared to the Jews in arguing that among these two peoples, "love for instruction" was especially diffused and that both were persecuted communities. As observed by Michel Bruneau, Reclus might be considered one of the first geographers of diasporas (Bruneau 2005). However, Reclus's early denunciations of pogroms in Russia and of the Armenian genocide were not his only original ideas. Differing from current

${ }^{68}$ ULB, IZ 457, 1896-97, Carnet 5 Lecture 14, Platteel's notes.

${ }^{69}$ ULB, IZ 457, 1896-97, Carnet 4 Lecture 13, Syllabus.

${ }^{70}$ ULB, IZ 457, 1896-97, Carnet 4 Lecture 13, Platteel's notes.

${ }^{71}$ ULB, IZ 457, 1896-97, Carnet 4 Lecture 13, Platteel's notes.

"Teaching anarchist geographies: Elisée Reclus in Brussels and 'the art of not being governed", Annals of the American Association of Geographers, 108(1), 2018, p. 162-178 http://www.tandfonline.com/doi/full/10.1080/24694452.2017.1339587 24 
commonplace thoughts, he considered these massacres to be a product not of "Oriental despotism" but of the imperial action of power. In the Armenian case, "persecutions and massacres [were] inspired not by the Turkish religious fanaticism, but by rulers' fear and hate for freedom." 72 Addressing Armenian cultural activities, Reclus mentioned groups of political dissidents and exiles that were represented in the New University: "Armenians translate foreign works, study sciences, have numerous print shops, journals addressing the topics which interest the entire humankindthe social question." ${ }^{73}$ Reclus stated the responsibility not only of the Turkish Empire but also of the Russian one: "Jews and Armenians are educated, thus they are not the fittest subjects for a regime pretending absolute compliance." Drawing on direct witnesses, Reclus denounced the cultural war against the Armenians that was fought in the name of russification on the Russian watershed. "In schools, it is forbidden to teach Armenians' history, geography and language. ... The Armenians willing to be instructed claim for the creation of a university in Tiflis, but the Russians are opposed and students must go abroad, where despite all they learn that they have right to freedom as everyone." 74 These notes help to understand the strategic importance of instruction as the first drive for social transformation in Reclus's political agenda.

On the Turkish side of the border, Reclus noticed an initial major tolerance about language, identity and religion for the Armenian community, which then ended for reasons of imperial diplomacy. After the 1877-78 war, the Turkish Empire was in a weak position vis-à-vis Russia, and around 1890, the sultan was requested by the czar to repress the Armenian claims for autonomy, which threatened Russian politics. "Russia denounced this to the Sultan as a danger because Armenians had advanced ideas and their literature inspired socialists and even anarchists. Authorities, knowing that Armenians were suspected, started persecuting them. In 1890, in Erzurum, an Armenian cathedral was burnt and several Armenians were massacred. Since, massacres occurred methodically, as Muslims knew that everything were allowed against Armenians. ... The Sultan's guard proceeded to the destruction work from [one] province to the other. There were 900,000 victims and horrible things occurred; the easiness of crime accentuated the atrocities." 75

\footnotetext{
${ }^{72}$ ULB, IZ 457, 1896-97, Carnet 5 Lecture 17, Syllabus

${ }^{73}$ ULB, IZ 457, 1896-97, Carnet 5 Lecture 17, Platteel's notes

${ }^{74}$ ULB, IZ 457, 1896-97, Carnet 5 Lecture 17, Platteel's notes

${ }^{75}$ ULB, IZ 457, 1896-97, Carnet 5 Lecture 17, Platteel's notes

"Teaching anarchist geographies: Elisée Reclus in Brussels and 'the art of not being governed", Annals of the American Association of Geographers, 108(1), 2018, p. 162-178 http://www.tandfonline.com/doi/full/10.1080/24694452.2017.1339587 25
} 
The responsibilities of European empires were equally highlighted. "Why is Europe tolerating these massacres? Because the Sultan does not feel isolated in the world of rulers. ... Do not the English have to their credit the massacre of the Matabele? And if the French ambassador complained, any Turkish might [evoke] the massacre of Communards. The Sultan's problem is to get rid of dissidents, and this theory rules in both Orient and Occident." ${ }^{76}$ The only solution Reclus could see was not state intervention but local agency and international solidarity. "In Zeitun, where Armenian populations resisted strongly, their independence was acknowledged but everywhere the massacres of 90 were followed by others in $92,93,94,95,96 . \ldots$ And Tolstoy preached the nonresistance to evil! We must resist the evil with all our energy, because if we leave our friend alone, we sacrifice the freedom of all humankind, and ours." 77 Thus, Reclus seized the occasion of his modules to clarify his idea of anarchism, a far cry from bombs and violence but also from Tolstoy's passive resistance: oppressed people have the right to struggle for their freedom. The conclusion of this module clarified the last point of this non-statist geography: multilingualism and mutual understanding as anti-imperial devices: "Babylonia must be built again. ... A free Babylonia which will no more be the prey of any Nebuchadnezzar or Alexander." 78

\section{Conclusions}

This paper has shown the importance of empathy toward others, non-statist lenses for reading the world and anti-colonial imagination for informing the contents of early anarchist geographical pedagogies. In such pedagogies, frameworks of comparison and area studies were used not as ethnocentric devices but as instruments to understand differences and foster solidarity. Researchoriented approaches and voluntarism prevailed over utilitarian interest for marks and degrees, while internationalisation and multilingualism enhanced the dissemination of these contents. An example is furnished by Dirlik, who mentions the engagement of Chinese militants who were in contact with the New University in the Shanghai "Labour university" (Dirlik 1991, 24), thus fostering the conversation between East and West for which Reclus wished.

\footnotetext{
${ }^{76}$ ULB, IZ 457, 1896-97, Carnet 5 Lecture 17, Platteel's notes

${ }^{77}$ ULB, IZ 457, 1896-97, Carnet 5 Lecture 17, Platteel's notes

${ }^{78}$ ULB, IZ 457, 1896-97, Carnet 6 Lecture 18, Platteel's notes

"Teaching anarchist geographies: Elisée Reclus in Brussels and 'the art of not being governed", Annals of the American Association of Geographers, 108(1), 2018, p. 162-178 http://www.tandfonline.com/doi/full/10.1080/24694452.2017.1339587 26
} 
Regarding the problem of "how to teach", Reclus's lectures clarify that the main target was not to indoctrinate but to help the autonomous building of students' critical thinking abilities (Codello 2005). Though the other attendee whose recollections survive, Dejongh, stated that Reclus's modules "never were a pretext for anarchist propaganda", ${ }^{79} \mathrm{I}$ argue that for Reclus, anarchist teaching was what Chatterton calls "not just to teach injustice, but to empower students to become active, critical and defiant citizens who are engaged in social changes ... fostering a sense of freedom rather than indoctrination" (Chatterton 2008, 421). Platteel's biography was that of an emancipated woman and an unconventional individual; it is possible to suppose that her experience at the New University might have helped her make those choices.

The main insights that Reclus's experience can provide into today's anarchist geographical pedagogical debates between academia and de-schooling are that all spaces, institutional or not, can be used by teachers and activists to perform a critique of the establishment and a programme of "freed education". It also shows that the educational dimension of anarchist geographies has no age, because it draws simultaneously upon traditions concerning primary teaching, higher education and lifelong learning.

\section{References}

Anderson, B. 2007. Under three flags: anarchism and the anti-colonial imagination. London: Verso.

Anderson, B. Life beyond boundaries. London: Verso.

Araujo E. 2016. What do we resist when we resist the state? In Theories of resistance. Anarchism, geography and the spirit of revolt, eds. M. Lopes de Souza, R. White and S. Springer, 79-100. London-New York, Rowman and Littlefield.

Avrich, P. 2006. The Modern School Movement: anarchism and education in the United States. Oakland, CA: AK Press.

Barclay, H. 1996. People without government, an anthropology of anarchy. London: Kahn and Averill.

${ }^{79}$ ULB, IZ 453, T. Dejongh, Les Reclus ..., p. 22.

"Teaching anarchist geographies: Elisée Reclus in Brussels and 'the art of not being governed", Annals of the American Association of Geographers, 108(1), 2018, p. 162-178 http://www.tandfonline.com/doi/full/10.1080/24694452.2017.1339587 27 
Brun, C. 2015. Elisée Reclus, une chronologie familiale. Raforum, http://raforum.info/reclus/spip.php?article455

Bruneau, M. 2013. Élisée Reclus et la géographie des diasporas. In Élisée Reclus et nos géographies, textes et prétextes, eds. I. Lefort and P. Pelletier. Paris: Noir et Rouge.

Castree, N., Fuller, D., Kent, A., Kobayashi, A., Merrett, C. D., Pulido, L., and Barraclough, L. 2008. Geography, Pedagogy and Politics. Progress in Human Geography 32(5): 680-718.

Chakrabarty, D. 2000. Provincializing Europe: postcolonial thought and historical difference. Princeton: Princeton University Press.

Chatterton, P. 2008. Using geography to teach freedom and defiance: lessons in social change from autonomous geographies. Journal of Geography in Higher Education 32(3): 419-40.

Clark, J.P. and C. Martin. Anarchy, geography, modernity: selected writings of Elisée Reclus. Oakland: PM Press, 2013.

Codello, F. 2005. La buona educazione: esperienze libertarie e teorie anarchiche in Europa da Godwin a Neill. Milano: Angeli.

Despy-Meyer, A. 1973. Inventaire des Archives de l'Université Nouvelle.de Bruxelles (1894-1919). Brussels : Archives de l’Université Libre.

- 1986. L'Institut Géographique de l'Université Nouvelle. Revue Belge de Géographie 110 (1): 53-68.

Dirlik, A. 1991. Anarchism in the Chinese Revolution. Berkeley: University of California Press.

Dunbar, G. 1978. Élisée Reclus: historian of nature. Hamden: Archon Books.

Elden, S. 2013. The birth of territory. Chicago: University of Chicago press.

Ferretti, F. 2011. The correspondence between Élisée Reclus and Pëtr Kropotkin as a source for the history of geography. Journal of Historical Geography 37: 216-222

— 2013a. They have the right to throw us out': Élisée Reclus' New Universal Geography. Antipode 45 (5): 1337-55.

— 2013b. De l'empathie en géographie et d'un réseau de géographes. La Chine vue par Léon Metchnikoff, Élisée Reclus et François Turrettini. Cybergeo http://cybergeo.revues.org/26127

— 2014. Élisée Reclus. Pour une géographie nouvelle. Paris: CTHS.

"Teaching anarchist geographies: Elisée Reclus in Brussels and 'the art of not being governed", Annals of the American Association of Geographers, 108(1), 2018, p. 162-178 http://www.tandfonline.com/doi/full/10.1080/24694452.2017.1339587 28 
- 2016a: The spatiality of geography teaching and cultures of alternative education: the 'intuitive geographies' of the anarchist school in Cempuis (1880-1894). Cultural Geographies 23(4): 615-633.

- 2016b. Radicalizing pedagogy: Geography and libertarian education between the $19^{\text {th }}$ and the $20^{\text {th }}$ century". In Transgressing Frontiers, eds. S. Springer, R. White, M. Lopes de Souza, 51-72. New York: Rowman \& Littlefield.

- 2017. The murderous civilization: anarchist geographies, ethnography and cultural differences in the works of Elie Reclus. Cultural Geographies 24(1) 111-129.

Graeber, D. 2004. Fragments of an Anarchist Anthropology. Chicago: Prickly Paradigm Press.

Halperin J. 1991. Félix Fénéon, art et anarchie dans le Paris fin de siècle. Paris: Gallimard.

Jöns H., P. Meusburger and M. Heffernan. 2017. Mobilities of Knowledge. Springer.

Illich, I. 1970. Deschooling Society. New York: Harrow.

Ince, A. and G. Barrera de la Torre. 2016. For post-statist geographies. Political Geography 55 (1): 10-19.

Kalterfleiter C. and A. Nocella II. 2012. Anarchy in the academy: staying true to anarchism as an academic activist. In Anarchist pedagogies: collective actions, theories, and critical reflections on education, ed. R. Haworth, 200-217. Oakland: PM Press.

Kearns, G. 2009. Geopolitics and Empire, the legacy of Halford Mackinder. Oxford: Oxford University Press.

Jazeel, T. 2014. Subaltern geographies: geographical knowledge and postcolonial strategy. Singapore Journal of Tropical Geography 35 (1): 88-103.

Konishi, S. 2013. Anarchist Modernity: cooperatism and Japanese-Russian intellectual relations in modern Japan. Cambridge: Harvard University Press.

Legg, S. 2016. Empirical and analytical subaltern space? Ashrams, brothels and trafficking in colonial Delhi Cultural Studies 30: 793-815.

Livingstone, D. 2003. Putting science in its place, geographies of scientific knowledge. Chicago: Chicago University Press.

Mathewson, K. 2016. Elisée Reclus' latin americanist geography. Terra Brasilis http://terrabrasilis.revues.org/1849

Metchnikoff, L. 1886. Revolution and Evolution. Contemporary Review, 412-437.

"Teaching anarchist geographies: Elisée Reclus in Brussels and 'the art of not being governed", Annals of the American Association of Geographers, 108(1), 2018, p. 162-178 http://www.tandfonline.com/doi/full/10.1080/24694452.2017.1339587 29 
- 1889. La civilisation et les grands fleuves historiques. Paris: Hachette.

Morris, B. 2014. A Brian Morris reader. Oakland: PM Press.

Noterman, E., and A. Pusey. 2012. Inside, outside, and on the edge of the Academy: experiments in radical pedagogies. In Anarchist pedagogies: collective actions, theories, and critical reflections on education, ed. R. Haworth, 175-99. Oakland: PM Press.

Pelletier, P. 2013. Géographie et anarchie: Reclus, Kropotkine, Metchnikoff. Paris: Éditions du Monde Libertaire.

Perron, C. 1868. De l'obligation en matière d'instruction. Geneva: Tipographie Vaney.

Picard, E. 1894. Une nouvelle université à Bruxelles. La Société Nouvelle, 10 (1): 627-645.

— 1897. L'Institut des Hautes Études à l'Université Nouvelle. L'Humanité Nouvelle 1 (1): 550567.

Powell, R.C. (2007). Geographies of science: histories, localities, practices, futures. Progress in Human Geography, 31(3): 309-329.

Pulido, L., and L. Barraclough. 2008. A people's guide to Los Angeles, an experiment in popular geography. In Castree et al., 708-714.

Ramnath, M. 2011. Decolonizing anarchism: an antiauthoritarian history of India's liberation struggle. London: AK Press.

Randall, A. 2002. Anarchist pedagogies for peace. Peace Review, 14 (4): 433-439.

Reclus, E. 1880. Histoire d'une montagne. Paris, Hetzel.

- 1882. Nouvelle Géographie universelle, vol. VII, l'Asie orientale. Paris: Hachette.

- 1894a. Leçon d'ouverture du cours de géographie comparée dans l'espace et dans le temps. Bruxelles: Lamertin.

- 1894b. Extension universitaire de Bruxelles. Comité local d'Arlon. Cours de géographie (Amérique méridionale). Bruxelles: Imprimerie Moreau.

- Université nouvelle de Bruxelles: séance solennelle de rentrée du 22 octobre 1895. Bruxelles: Imprimerie Larcier, http://raforum.info/reclus/spip.php?article9\&lang=fr

- 1897. Quelques mots sur la révolution bouddhique. L'Humanité Nouvelle 1 (1): 139-145.

- 1903. 'On spherical maps and reliefs', The Geographical Journal (3): 290-293.

- 1905. L’Homme et la Terre, vol. V. Paris: Librairie Universelle.

- 1911. Correspondence, vol. 1. Paris: Schleicher.

"Teaching anarchist geographies: Elisée Reclus in Brussels and 'the art of not being governed", Annals of the American Association of Geographers, 108(1), 2018, p. 162-178 http://www.tandfonline.com/doi/full/10.1080/24694452.2017.1339587 30 
Reclus E. et al. 1898. La liberté par l'enseignement (l'école libertaire). Paris: Editions des Temps Nouveaux.

Robic, M.C., J.L. Tissier and P. Pinchemel. 2011. Deux siècles de géographie française : choix de textes. Paris: CHTS.

Rouhani, F. 2012. Practice what you teach: facilitating anarchism in and out of the classroom. Antipode, 44 (5): 1726-1741.

Said, E. 1978. Orientalism. New York: Vintages Books.

Scott, J. 2009. The art of not being governed, an anarchist history of upland Southeast Asia. New Haven: Yale University Press.

Sidaway, J.D., E. LE Ho, J.D. Rigg and C.Y. Woon. 2016. Area studies and geography: trajectories and manifesto. Environment and Planning D. 34(5): 777-790.

Springer, S. 2015. Violent Neoliberalism: Development, Discourse, and Dispossession in Cambodia. London: Palgrave.

- 2016a. The Anarchist roots of geography: toward spatial emancipation. Minneapolis: University of Minnesota Press.

— 2016b. Learning through the soles of our feet. In The Radicalisation of Pedagogy. Anarchism, Geography and the Spirit of Revolt, 247-265.

— 2017. Earth Writing. GeoHumanities http://dx.doi.org/10.1080/2373566X.2016.1272431 [early view]

Springer, S., A. Barker, G. Brown, A. Ince, and J. Pickerill. 2012. Reanimating anarchist geographies: a new burst of colour. Antipode, 44 (5): 1591-1604.

Springer, S., R. White and M. Lopes de Souza (eds). 2016. The Radicalisation of Pedagogy. Anarchism, Geography and the Spirit of Revolt. New York: Rowman \& Littlefield.

Suissa, J. 2010. Anarchism and education: a philosophical perspective, Oakland: PM Press.

Uyttebrouck A. 1986. L'incident Reclus vu à travers les archives officielles de l'Université Libre de Bruxelles. Revue Belge de Géographie 110 (1): 23-68.

Van Rooy, W. 1976. L'Agitation étudiante et la fondation de l'Université Nouvelle en 1894. Revue Belge d'Histoire Contemporaine 1-2: 197-241

"Teaching anarchist geographies: Elisée Reclus in Brussels and 'the art of not being governed", Annals of the American Association of Geographers, 108(1), 2018, p. 162-178 http://www.tandfonline.com/doi/full/10.1080/24694452.2017.1339587 31 
Vicente-Mosquete T. 2004. Geografía y ciencia en la Universidad Nueva de Bruselas, 1894-1919. Actas VIII Congreso de la Sociedad Española de Historia de las Ciencias y de las Técnicas. Logroño, Universidad de la Rioja, 937-957.

- 2008. Elisée Reclus y su aportación a la cartografía, Segon Congrés Català de Geografia, 29 - 31 de maig, 478-494.

\section{Acknowledgements}

This work was supported by the UCD College of Social Sciences and Law, within the research project 'Early critical and anti-colonialist geographies', grant number R15975. Special thanks to Alun Jones for supporting my research at UCD, to Simon Springer for his feedback and suggestions on this paper, to René Fayt and Colette De Schutter for facilitating my archival research in Brussels. Finally, a great thanks to the reviewers for the Annals and to the editor, Nik Heynen, for their precious suggestions.

\section{Author's biography}

Federico Ferretti received his $\mathrm{PhD}$ from the Universities of Bologna and Paris 1 PanthéonSorbonne. After research and teaching experiences in Italy, France, Switzerland and Brazil, he is now Lecturer in Human Geography in the School of Geography at University College Dublin. His research interests lie in philosophy and history of geography and in cultural history, with a special focus on the international circulation of geographical knowledge and on critical and anarchist approaches.

"Teaching anarchist geographies: Elisée Reclus in Brussels and 'the art of not being governed", Annals of the American Association of Geographers, 108(1), 2018, p. 162-178 http://www.tandfonline.com/doi/full/10.1080/24694452.2017.1339587 32 